\title{
Management of Customary Marine Rights in Regional Autonomy Era in Kei Islands
}

\author{
Sri Wahyu Ananingsih \\ Universitas Diponegoro \\ Semarang, Indonesia \\ ayu_fhundip@yahoo.com
}

\begin{abstract}
Customary marine rights are owned by the indigenous community to manage marine in their territories. This research aimed to understand challenges and opportunities of customary marine rights management in regional autonomy era in Kei Islands. Some interview studies were conducted to understand the challenges and opportunities of it. It is concluded that the challenges of customary marine rights management in regional autonomy in Kei Islands are improvement of good communication among the local government, the headman and customary leaders; improvement of local community empowerment; the urgent need is the existence of local regulation related to recognition and protection of customary rights, including customary marine rights. The opportunities of customary marine rights management in Kei Islands have increased family income for Kei people and local government income.
\end{abstract}

Keywords - management customary marine rights, regional autonomy, challenges and opportunities, Kei Islands.

\section{INTRODUCTION}

Customary marine rights are also known as customary marine tenure. The term of "customary" refers to a system that come from traditional roots, a part of customary law and related with local history as it adapts to changing contemporary circumstances; "Marine" refers to a system related with reefs, lagoons, coasts and open sea including islands and islets in this overall sea space; "Tenure" refers to a social process related with control over territory and access to resources[1] Base on the term, customary marine rights include management of using rights, controlled access, the existence of customary rules and its enforcement. Under the customary marine tenure system, marine areas like reefs, lagoons, littoral zones, low- lying coral islets and inshore fishing ground are owned by social groups, in some societies at the tribe level while at the clan level in others [2], See to Carrier [3] and Ward [4]. Customary marine tenure has been published in Japan [5], Pasific [6], [7], in Papua New Guinea by Hyndman [8] and Adjaye [9].

In Indonesia, customary marine rights are owned by indigenous communities to manage marine in their territories. These rights are dynamic and highly adaptive and usually called as community-base fisheries management institution [10]. Many regions in Indonesia still recognize and acknowledge customary marine rights such as Papua, Aceh, Maluku and Kei Islands. People usually use customary marine rights to fulfill their daily living needs. The headman regulates these rights for society interests. He also determines law enforcement of customary marine rights violation. In Kei Islands, customary marine rights are based on the customary law called as "Larvul Ngabal". They are used not only local people but also outsiders. They can use these rights if the headman gives permission. Besides permission, the outsiders must give some money (it is called "sirih pinang") to the headman when they want to use customary marine rights. The amount of money which given to the headman depend on the large and productivity of an area [11].

Regional autonomy in Indonesia has begun in 1999. It was known as decentralization era. In this era, a region has authority and rights to manage its own region including Kei Islands-Southeast Maluku Regency. The management of customary marine rights is affected by the impact of regional autonomy. Base on the impact of regional autonomy, this study find challenges and opportunities to customary marine rights management in Kei Islands. Both of them must be known by the local government and Kei people. For the local government, these data can be considered to make government policy. For Kei people, they are useful to make a new strategy in customary marine rights management.

\section{RESEARCH METHODOLOGY}

The area which forms the background of this study is located in Kei Islands, Southeast Maluku Regency (fig.1). It is an area of approximately $55,932 \mathrm{~km}^{2}$. It consists of land area $4,049 \mathrm{~km}^{2}$ (7\% of total area) and sea area about 51,883 $\mathrm{km}^{2}$ (93\% of total area). There are approximately 119 small islands but just only 100 islands are inhabited by people [12]. Southeast Maluku Regency consist of 11 sub-districts and the majority of people live in Kei kecil sub-district. Fisheries subsector is the largest potential of all existing resources in Kei Islands. That is a reasonable fact because $93 \%$ of the total area in the region is marine area.

The methods of this study: first, the Law with regard to the implementation of regional autonomy were examined. In this direction, there are some regulations related to regional autonomy in the Constitution, Law No.22/1999, Law 
No.32/2004 and Law No.23/2014 on Regional Government. Data were collected by literature studies. Second, collection of data in the field. They were collected by interviews. In this direction, interviews were conducted with the aim of understanding the implementation of Law No.23/2014 and customary marine rights in Kei Islands. Third, data from literature studies and interviews were analyzed by qualitative analysis. The findings of this study were summarized in subtitles.

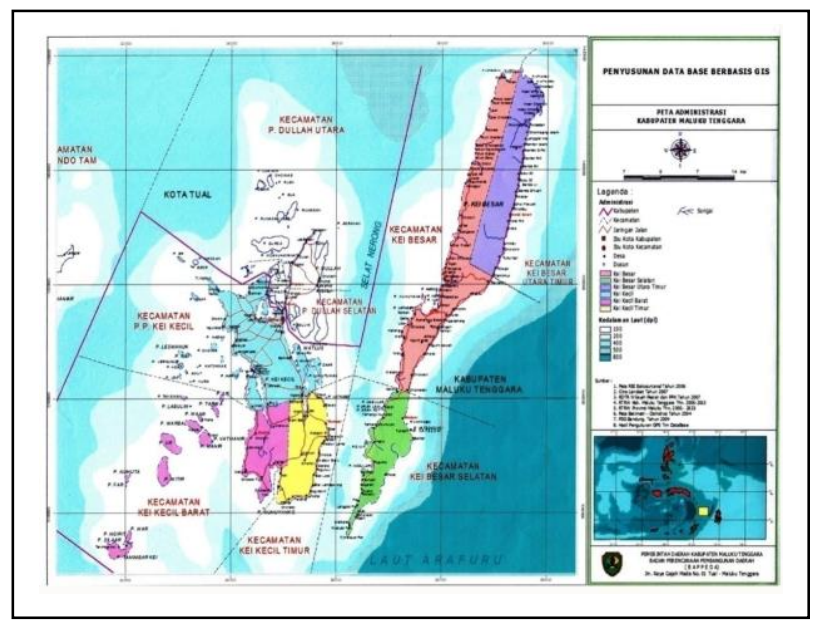

Fig.1 Study Area: Kei Islands, Southeast Maluku Regency, Indonesia

\section{RESULTS AND DISCUSSION}

Regional autonomy in Indonesia has begun in 1999. It was known as decentralization era. It has adopted to loosen the tight control of the central government over the regions and entrust them with self-governing authority [13]. The first regulation was Law No.22/1999 on Regional Government. Under the Law, authority was granted to two levels of regional government. On one hand in provinces and on the other hand districts and cities [14]. The general explanation of Law No.22/1999 said that Indonesia as a unitary state adheres to the principle of decentralization in governance that gives opportunity and freedom to regions to manage their own regions. An interesting clause in the 1999 statute is that village communities have own autonomy and rights and that local communities do not necessarily have to adhere to the form of "desa" as it set out in Law No.5/1979 [15].

The Law No.22/1999 was replaced by Law No.32/2004. and in 2014 Law No.23/2014 was applied by government. It was replaced Law No.32/2004. The Law No.23/2014 affirms again that the local government has authority and rights to manage their own region. Article 13 paragraph (4) Law No.23/2014 states clearly that criteria administrative affairs under the authority of districts or cities are government affairs which are located in the districts or cities; government affairs who the user are in the districts or cities; government affairs that benefits or negative impacts just only in the districts or cities; and government affairs that more efficient using resources in the districts or cities.

Regarding article 13, Article 31 paragraph (1) states that in the implementation of decentralization is used regional planning. Paragraph (2) defines that the regional planning is intended to realize the effectiveness of the regional administration; to push forward the improvement of prosperity for society; to push forward the improvement of public services quality; to improve good governance, national and regional competitiveness and to protect the uniqueness of customs, traditions, and regional culture.

In 2003, Kei Islands, Southeast Maluku regency was divided into Southeast Maluku Regency and Aru Islands Regency. In 2007, Southeast Maluku Regency dispart to be Tual City and Southeast Maluku Regency (Fig.2.). In fact, the proliferation new region in 2007 separated of several "ohoi" (village) and "soa" (the small unit of government under "ohoi" (village) in four "ratchaps" (consist of several villages). The ratchaps were Tual, Yarbadang, Ohoitel and Dullah. They were separated in Tual city and Southeast Maluku Tenggara regency.

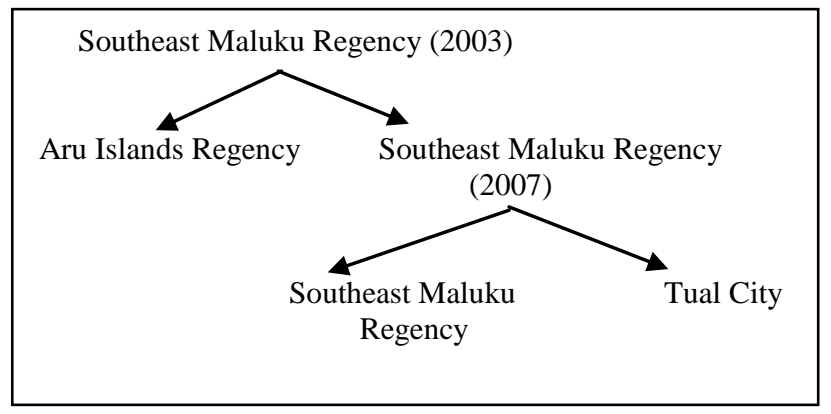

Fig 2. Proliferation of new administrative regions in Kei Islands

In autonomy era, related to marine resources, as a matter of fact many investors are interested in Kei. It is evidenced by the increasing of outsiders who use customary marine rights. Most of them usually use their area for fish farm and trade, seaweed or pearl farm and it takes decades. On the contrary, there are few outsiders interest in tourism sector even though Kei has some beautiful beaches such as Ngur sarnadan beach, Ngurbloat beach, Pasir timbul ngurtavur beach, Bair islands and Ngodan beach.

The outsiders use customary marine territories not for fulfillment daily needs but business purposes. They use for years (10-30 years). Although they have permittance and give money (it is called "sirih pinang") to the headman, the using for years cause local people incur losses of it. They can not access marine in their villages for a long time. Besides that, the using of outsiders for years have possibility to damage the environment and marine ecosystems.

Customary marine rights are very important in Kei people life. They use these rights to support the daily living needs. But in fact, not only Kei people which can use these rights, outsiders also can use them. Considering this, in autonomy era, there are challenges for customary marine rights management in Kei. For the local government: first, improvement of good communication and coordination among the local government, the headman and customary leaders. In the perspective of regional autonomy, the proliferation of new region as a necessity. The purpose of it are to increase the effectiveness of governance; improve the implementation of 
development and social development; accelerate the realization of equal distribution of public welfare; and service closer to the community and more effectively supervisory control. But in the process, the local government must give chance to the headman and customary leaders to participate in decision making. It is very important to do because they represent Kei people. The important thing of it, the local government should not separate customary territories. Although the separation just for government administration, but in fact it is difficult for customary leaders to coordinate their territories.

Second, improvement of local community empowerment. Kei has potency in natural resources such as fishes, seaweed, sea cucumber and pearl but the local people empowerment still lacking. At this time, just people in some villages: Evu village, Letvuan village, Wab village, Kelanit village, Sathean village, Faan village and Warbal village have made seaweed cultivation. Meanwhile fishes farm and sea-pearl cultivation are still dominated by outsiders. In fact, fishery production abundant in the west wind season but local markets are lack of buyers. The impact of this condition, many fishes are thrown away. It means local people need fishes processing and marketing system. As the same as in sea-pearl cultivation. No one of Kei people have sea-pearl cultivation business in Kei. All of the pearl businessmen are outsiders. Now, it is time for the local government to improve local people empowerment in fish management and pearl cultivation. Surely, the improvement of empowerment include marketing solution. The empowerment is not only useful to increase Kei family income but also local revenue.

Third, the urgent need is the existence of local regulation related to recognition and protection of customary rights, including customary marine rights. It is an urgent need in order to protect the existence of customary rights. Outsiders can use customary marine rights so protection of customary rights is very important. Besides that, it is needed to restrict the time of use for outsiders. It can reduce the risk of environment damage. A good communication and coordination among the customary leaders in Kei are also needed to discuss about it.

The opportunities of customary marine rights management in autonomy era in Kei Islands are first, to improve management natural resources, especially for local people. Second, increase family income and local revenue. Third, preserve natural resources from environment damage. Fourth, improve in tourism sector. The success of customary marine rights management will affect the success of regional autonomy in Kei.

\section{CONCLUSION}

The challenges of customary marine rights management in regional autonomy in Kei Islands include first, improvement of good communication among the local government, the headman and customary leaders, especially in the proliferation new region. Second, improvement of local community empowerment. Kei has natural resources potential but in fact, the local people empowerment still lacking. Third, the urgent need is the existence of local regulation related to recognition and protection of customary rights, including customary marine rights. The opportunities of customary marine rights management in regional autonomy in Kei Islands are first, to improve management natural resources, especially for local people. Second, increase family income and local revenue. Third, preserve natural resources from environment damage. Fourth, improve in tourism sector.

\section{REFERENCES}

[1] G. Bennett, "Customary marine tenure and contemporary resource management in Solomon Islands," Proc. 12th Int. Coral Reef Symp., vol. 22, no. July, p. p.9-13, 2012.

[2] E. Hviding, All Things in Our Sea: The Dynamics of Customary Marine Tenure, Marovo Lagoon, Solomon Islands, no. No.13. National Research Institute, Boroko, 1998.

[3] J. Carrier, "Marine tenure and conservation in Papua New Guinea," in The Question of the commons: the culture and ecology of common resources., and J. A. B. McCay, Ed. Tucson, Arizona, USA.: The University of Arizona Press, 1987, p. Pp.143-167.

[4] G. Ward, "Changing forms of communal tenure," in The governance of common property in the Pacific Region, P. Larmour, Ed. Canberra, Australia.: National Centre for Development Studies, Australian Nation University, 1997, p. p.13.

[5] K. and T. A. (eds) Ruddle, "Introduction National Museum of Ethnology, Osaka, Japan.," in Maritime institutions in the Western Pacific, Osaka, Japan: National Museum of Ethnology, 1984.

[6] S. Aswani, "Common property models of sea tenure: A case study from the Roviana and Vonavona Lagoons, New Gorgia, Solomon Islands," Hum. Ecol., vol. Vol.27, no. 3, p. pp.417-453, 1999.

[7] R. Putney, "Customary Marine Tenure and Traditional Ecological Knowledge in Palau," San José State University, 2008.

[8] D. Hyndman, "Sea Tenure and The Management of Living Marine Resources in Papua New Guinea," Pac. Stud., vol. Vol.16, no. No.4, p. pp.99-114, 1993.

[9] J. Asafu-Adjaye, "Customary marine tenure systems and sustainable fisheries management in Papua New Guinea," Int. J. Soc. Econ., vol. 27, no. 7/8/9/10, p. pp.917-927, 2000.

[10]C. Bailey, Conner and Zerner, "Community-Base Fisheries Management Institution in Indonesia." [Online]. Available: http://www.marecentre.nl/mast/documents/communitybasedfisheriesmana gementinstitutioninIndonesia.pdf.

[11]S. W. Ananingsih, "The Developments of Customary Marine Rights A Case Study in Kei Islands, Southeast Maluku Regency," Int. J. Wetl. Environ. Manag., vol. Vol.2, no. No.2, p. pp.67-73, 2014.

[12]Pemerintah Kabupaten Maluku, Rencana Pembangunan Jangka Menengah Daerah Kabupaten Maluku Tenggara Tahun 2008-2013. 2009.

[13]C. M. Sidjaya, "Regional autonomy concept: Feudalism in disguise?," The Jakarta Post, Jakarta.

[14] Simon Butt, "Regional Autonomy and Legal Disorder: The Proliferation of Local Laws in Indonesia," Syd. Law Rev., vol. 32-177, pp. 177-191, 2010.

[15]R. Simarmata, "Regional Autonomy and the Character of Local Government Laws and Regulations New Pressures on the Environment and Indigenous Communities A Preliminary Diagnosis," in International Association for the Study of Common Property 9th Biennial Conference, Victoria Falls, Zimbabwe, 2002, pp. 3-14. 